\title{
Rape in Finnish criminal law and process - A discussion on, and beyond, consent
}

\author{
DANIELA ALAATTINOĞLU* ${ }^{*}$ HEINI KAINULAINEN*, JOHANNA NIEMI***
}

\section{Rape: A section in change}

The legislative definition of rape is a subject of lively debate in Finland, as in many other countries. Particularly influential developments for Finnish social and legal discussions on rape have been multiple. Among them are the problematisation of sexual violence during the international and national \#metoo-movements and their aftermath and supranational normative developments regarding the definition of rape and other sexual offences. Also, comparative legal developments, such as the Swedish legislative amendment in 2018 which emphasised involuntary participation as the defining element for rape as a criminal offence, ${ }^{1}$ have been important. In the light of these developments, the chapter that regulates sexual offences in the 1889 Finnish Criminal Code is currently undergoing a full revision in order to emphasise the fundamental rights to personal integrity and sexual autonomy. ${ }^{2}$ The chapter was

Icelandic Research Fund Postdoctoral researcher, Faculty of Law at the University of Iceland. Email: daniela@hi.is.

** Senior lecturer, Docent, Faculty of Law at the University of Turku. Email: heini.kainulainen@ utu.fi.

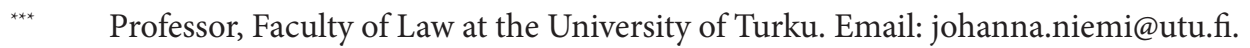

This article draws on a research project on the attrition of sexual crimes in the criminal process carried out at the University of Turku in 2019-2020. In the group, Heini Kainulainen was the project leader, Daniela Alaattinoğlu was the principal researcher and Johanna Niemi was a member of the research group. The research was commissioned by the Ministry of Justice. The article has been authored with support from the Swedish Cultural Foundation in Finland.

$1 \quad$ Swedish legislative amendment SFS 2018:618.

$2 \quad$ See Finnish Ministry of Justice Report 2020:9.

This is an Open-access article distributed under the terms of the Creative Commons Attribution 3.0 Unported License (http://creativecommons.org/licenses/ by/3.0/), permitting all use, distribution, and reproduction in any medium, provided the original work is properly cited. 
last completely remodelled in the late $1990 \mathrm{~s},{ }^{3}$ but has been subject to a patchwork of reforms during the last decades.

This article investigates the ongoing challenges to, and reorienting of, Finnish law on rape. As such, it scrutinises the criminal legislative definition of rape and its implementation. More specifically, the article looks into the current definition of rape in the Finnish Criminal Code and explores its theoretical and practical challenges. The article compares the current law with the draft definition of rape suggested by the Ministry of Justice in July 2020. Doing so, it apprehends expected problems in the shift from criminalisation that builds on physical force and exploitation of a defenceless person to a model that emphasises voluntariness, communication, power imbalances and consent.

After this short introduction, the second section of the article depicts the current definition of rape in Finnish legislation. The third section explores how developing supranational normative standards have affected the Finnish legal conceptualisation of rape. The fourth section looks at legal practice, sharing the insights of a 2019-2020 research project that investigated the reasons behind the attrition of rape and other sexual offences in the Finnish criminal process. The fifth section analyses the earliermentioned draft law on rape against the arguments used by the Ministry of Justice. The sixth section comparatively discusses the current and suggested legislative definitions of rape. The conclusion highlights that it is important to support the new legal standards with theoretical discussion, resource allocation and training of law enforcement authorities for the legislative changes to be enforced in practice.

\section{The definition of rape in Finnish legislation}

\subsection{Sexual intercourse}

The Finnish Criminal Code defines rape as sexual intercourse surrounded by at least one of two circumstances. The first is the use or threat of (physical) force or other coercion, and the second is the exploitation of a defenceless person. Other sexual acts than intercourse that are surrounded by similar coercive circumstances are not considered as rape in Finland but might qualify as another sexual offence, such as coercion into a sexual act. $^{4}$

'Sexual intercourse' is defined in the Criminal Code as 'the sexual penetration of the body of another, by a sex organ or directed at a sex organ or anal passage' or

\footnotetext{
3 Finnish Government Bill 6/1997vp,pp. 161-190. See also Utriainen, Raiskaus rikosoikeudellisena ongelmana [Rape as a criminal legal problem] (Lapin yliopiston oikeustieteiden tiedekunta 2010) pp. 113-114. All Finnish laws and Government bills are available in Swedish, and the most central legislation is also available in English, at finlex.fi.

The Criminal Code of Finland (39/1889), Chapter 20 Section 4.
} 
'the insertion of the sex organ of another into the body of the offender. ${ }^{5}$ Insertion of fingers into the victim's vagina, for example, fulfils this description. ${ }^{6}$ Penetration is hence essential for the definition of rape. ${ }^{7}$

\subsection{Use or threat of (physical) force}

According to Section 1, Chapter 20 of the Finnish Criminal Code, a 'person who forces another into sexual intercourse by the use or threat of violence directed against the person shall be sentenced for rape to imprisonment for at least one year and at most six years. ${ }^{8}$ The use or threat of violence should be enough to have a decisive effect on the will of the other person. ${ }^{9}$ While the nature of the violence intended in the section is not specified in the preparatory works, based on Finnish criminal legal doctrine, it seems that the violence required is physical violence against a person. There are, importantly, no clear guidelines on which acts that are considered as physical violence, ${ }^{10}$ which might lead to inconsistencies in practice. ${ }^{11}$ Physical violence can also be indirect and directed against another person than the direct victim, or concern an act of violence that will take place in the future. ${ }^{12}$ Despite this focus on physical violence, it is important to highlight that there is no requirement that the victim physically resists the perpetrator. ${ }^{13}$

\subsection{Sexual exploitation of a helpless person}

According to the above-mentioned section on rape in the Finnish Criminal Code, also a person who 'by taking advantage of the fact that another person, due to': i)

The Criminal Code of Finland (39/1889), Chapter 20 Section 10, para. 1. Official translation. Finnish Supreme Court Decisions KKO:2017:69; KKO:2019:55

The focus on penetration has been criticised by feminist legal scholars such as Jokila, Tahdonvastainen suostumus ja liiallisen luottamuksen hinta: Raiskauksen ja muiden seksuaalirikosten oikeudellisen tiedon konstruktiot [Consent against one's will and the price of undue trust:Legalconstructionsofknowledgein Finnishsexualcrimes] (Suomalaisenlakimiesyhdistyksen julkaisuja 2010), p. 292; Niemi-Kiesiläinen, Naisia, miehiä vai henkilöitä: Seksuaalirikokset ja sukupuoli [Women, men or people: Sexual offences and gender], 2 Oikeus (1998) pp. 4-19. The Criminal Code of Finland (39/1889), Chapter 20 Section 1, para. 1. Official translation. In Finnish, the phrase used is murtaa toisen tahdon, which roughly translates to break the will of another'. See Finnish Government Bills HE 6/1997 vp, p. 172; HE 216/2013 vp, p. 5. In the Supreme Court case KKO:2013:96, for example, it was clarified that groping the victim, pushing her into the bedroom and sitting on top of her could be defined as violence (para. 46).

11 Acts such as grabbing and holding on to the victim can be differently evaluated in disparate situations, for example, depending on whether the act happens outdoors between strangers or in a domestic setting between acquaintances.

12 Finnish Government Bill HE 6/1997 vp, pp. 164, 172-173. See also Matikkala, Seksuaalirikokset [Sexual offences] in Keskeiset rikokset [Central criminal offences] eds. Frände et al. (Edita 2018) pp. 126-203, at 133-137.

13 Finnish Government Bill HE 216/2013 vp, p. 36. 
unconsciousness, ${ }^{14}$ ii) illness, iii) disability, iv) state of fear ${ }^{15}$ or v) another state of helplessness, 'is unable to defend himself or herself ${ }^{16}$ or to formulate or express his or her will, has sexual intercourse with him or her, shall be sentenced for rape. ${ }^{17}$

This type of rape hence builds on the concept of exploitation. Interestingly, while physical resistance is not required from victims of rape according to the preparatory works, the section highlights that the victim should be unable to defend himself or herself or to formulate or express his or her will. This formulation puts the victim and her abilities at the centre of the definition of rape.

The application of this definition has proven narrow in practice. In the Finnish Supreme Court case 2019:78, the Court evaluated the key terms 'unconsciousness' and 'state of helplessness' in relation to the victim being under the influence of alcohol. The victim had no memory of the sexual intercourse between her and the defendant, but she had 0.14 per mille alcohol in her blood 12 hours after the sexual intercourse. Such evidence of intoxication was not, according to the Court, enough to demonstrate that she had been unable to defend herself or to formulate or express her will. The Court stated:

'A person who is unconscious or sleeping is both defenceless and unable to express his or her will. The fact that a person has lost her memory because of alcohol use cannot, however, alone determine that she was unable to defend herself or formulate or express her will. The ability of a drunk person who is conscious and awake to defend herself, formulate her will and express it depends on the individual and is difficult to determine.'18 narcotics. See Finnish Government Bill HE 216/2013 vp, p. 5. she or he finds defending herself or himself too dangerous or because she or he is unable to function because of fear. See Finnish Government Bill HE 216/2013 vp, p. 6. 'because of a mental or physical obstacle cannot at all or at least remarkable stop another person's actions'. Finnish Government Bill HE 216/2013 vp, p. 5. [authors' translation] Before 2011, there was a difference between if the perpetrator had put the victim in a situation of helplessness or whether she or he merely exploited this situation. In the former case, the sexual abuse was considered rape, and in the latter, it was considered sexual exploitation, for which a lesser sentence applied. The latter case became classified as rape through a change of the law in 2011 (495/2011).

Finnish Supreme Court KKO:2019:78, para. 24. Authors' translation. 


\subsection{Other forms}

The section on rape also regulates when the crime is 'less serious', in which case a lesser sentence scale applies.

'If the rape, taking into consideration the pettiness of the threat or the other circumstances connected with the offence, is less serious when considered as a whole than the acts referred to in subsections 1 or 2 , the offender shall be sentenced to imprisonment for at least four months and at most four years. A person who forces another into sexual intercourse through other than the threat referred to in subparagraph 1 shall be sentenced in a similar manner. What is provided above in this subparagraph does not apply if violence has been used in the rape.19

According to the Government Bill establishing the section, rape is less serious if the perpetrator has only 'slightly threatened to use violence. ${ }^{20}$ However, the threat does not necessarily need to imply physical violence. A threat to 'reveal harmful information' about a person can also qualify. ${ }^{21}$ Nevertheless, a threat to end a relationship does not fulfil the legislative requirements. ${ }^{22}$

According to the fourth paragraph of the section on rape, attempted rape is punishable. ${ }^{23}$ Also in these cases, a lesser sentence applies. The Finnish Criminal Code also establishes that rape is aggravated if perpetrated under certain, legislated conditions. ${ }^{24}$

The Criminal Code of Finland (39/1889), Chapter 20 Section 1, para. 3. Official translation. Finnish Government Bill HE 216/2013 vp, p. 57. Authors' translation.

Ibid. Authors' translation.

Ibid.

The Criminal Code of Finland (39/1889), Chapter 20 Section 1, para. 4.

Rape is considered aggravated if:

'(1) grievous bodily injury, serious illness or a state of mortal danger is caused to another,

(2) the offence is committed by several people, or especially marked mental or physical suffering is caused,

(3) the victim is a child below the age of eighteen years,

(4) the offence is committed in a particularly brutal, cruel or humiliating manner, or

(5) a firearm, edged weapon or other lethal instrument is used or a threat of other serious violence is made,

and the rape is aggravated also when assessed as a whole, the offender shall be sentenced for aggravated rape to imprisonment for at least two years and at most ten years.

An attempt is punishable.'

The Criminal Code of Finland (39/1889), Chapter 20 Section 2. Official translation.

The draft law proposes only minor changes to the aggravating circumstances.

Finnish Ministry of Justice Report 2020:9, p. 255. 


\subsection{Criminal intent}

Similar to the most serious offences of the Criminal Code, criminal responsibility for rape in Finland is conditional upon criminal intent. Criminal intent means that the perpetrator understands that the victim, because of the perpetrator's violence or threat of violence, gives in to the will of the perpetrator. ${ }^{25}$ It can also mean that the perpetrator understands that the victim is in a helpless position, unable to defend herself or unable to form or express her opinion, and because of this reason engages in the sexual intercourse. ${ }^{26}$

\section{Towards consent: National developments in the light of changing supranational norms}

Societal changes often affect legal normative development. In a global world, moreover, the supranational and the national interact and the borders between the two blur. This is also the case when it comes to criminal law. During the last decades, international standards regarding the criminalisation of sexual violence and the state's duty to protect victims have developed. ${ }^{27}$ In Europe, particularly the case law of the European Court of Human Rights ${ }^{28}$ and the establishment of the 2011 Council of Europe Convention on preventing and combating violence against women and domestic violence (the Istanbul Convention $)^{29}$ have been important to regulate sexual violence. These developments, together with national civil society mobilisation efforts, such as the citizens' initiative for a consent-based definition of rape (Suostumus2018), ${ }^{30}$ have

Finnish Government Bill HE 216/2013 vp, p. 6.

Ibid., pp. 6-7.

For the development in international criminal law regarding sexual violence, see, for example, the Rome Statute of the International Criminal Court (1998), Articles 7 (1, g) and 8 (2, b, xxii; 2, e, vi); International Criminal Tribunal for the former Yugoslavia, The Prosecutor v. Dragoljub Kunarac, Radomir Kovač and Zoran Vuković. no. IT-96-23-T and IT-96-23/1-T (22.2.2001); International Criminal Tribunal of Rwanda, The Prosecutor v. Jean-Paul Akayesu, no. ICTR-96-4-T (2.9.1998); The Prosecutor v. Jean-Paul Akayesu, no. ICTR-96-4-A (1.6.2001). See also Eriksson, Defining rape: Emerging obligations for states under international law? (Martinus Nijhoff Publishers 2011).

Particularly important here is the landmark case M.C. v. Bulgaria, appl. no. 39272/98 (4.12.2003). The Court has since developed its rape jurisprudence regarding state obligations and victim protection. See, for example, the cases I.G. v. the Republic of Moldova, appl. no. 53519/07 (15.5.2012); I.C. v. Romania, appl. no. 36934/08 (24.5.2016); M.G.C. v. Romania, appl. no. 61495/11 (15.3.2016); E.B. v. Romania, appl.no. 49089/10 (19.3.2019).

2 See Council of Europe Convention on preventing and combating violence against women and domestic violence (The Istanbul Convention) Article 36 which regulates rape and sexual violence.

See citizens' initiative KAA 2/2019 vp. The initiative was discussed by the Finnish Parliament in September 2019 and sent to the Parliamentary Legal Affairs Committee for further legislative preparation. 
led to consent taking on a central role in Finnish criminal legal discussions.

Already in 2012-2013, the Finnish Government reflected upon changing the definition of rape by bringing (the lack of) consent to its centre. In its Bill 216/2013, the Government, however, considered such an amendment unnecessary and foreign to Finnish legal tradition. In addition to this, the Government Bill highlighted that consent in practice was important in the current definition of rape. ${ }^{31}$ As a prerequisite of introducing consent as an element of rape, the Government considered that specific regulations of the circumstances under which a valid consent cannot be given would be necessary. The Government nevertheless thought that such regulations would pose a challenge to the principle of free sifting of evidence by the courts. ${ }^{32}$ An explicit requirement of consent might also be foreign to how people generally behave sexually, as in sexual relations, one does not always explicitly inquire about the partner's consent and consent is neither always expressed explicitly. ${ }^{33}$ Furthermore, the Government argued that an explicit element of consent in the definition of rape might mean that the victim and their consent would become increasingly central in the court proceedings. This would, in turn, make the criminal process even more burdensome for the victims of rape. ${ }^{34}$ contribution of the victim and the responsibility of the perpetrator] (Edita 2004) p. 242. That consent has a place in Finnish legal practice regarding rape is visible in the Finnish Supreme Court case KKO:2013:96, see particularly para. 4.

$34 \quad$ Ibid., p. 38. See also Finnish Ministry of Justice Report 25/2012, pp. 59-67. 
The current Finnish law has nevertheless been subject to both international and national criticism. National legal and social science scholars have long criticised the regulation of rape and the inefficiency of the criminal process. ${ }^{35}$ According to the 2019 report on Finland by the Group of Experts on Action against Violence against Women and Domestic Violence (GREVIO), the monitoring organ of the Istanbul Convention, the Finnish legislation is problematic because it:

'[...] does not fully capture the realities of women experiencing sexual violence and how they respond to threat (i.e. flight, fight, freeze, flop or befriend). The consequence is that not all forms of sexual violence are criminalised in Finland, as required by the convention. ${ }^{36}$

According to GREVIO, the current Finnish legislation leads to "higher thresholds of evidentiary standards of physical resistance' together with a 'shifting of the focus onto the victim's behaviour rather than the accused's actions. ${ }^{37}$ In the report,

Important examples of such critical voices are Niemi-Kiesiläinen, Mitä seksuaalirikoslailla halutaan suojella? [What does the sexual offences legislation aim to protect?] in Lähentelyistä raiskauksiin. Tyttöjen kokemuksia häirinnästä ja seksuaalisesta väkivallasta [From sexual approaching to rape. Girls' experiences of harassment and sexual violence], eds. Honkatukia, Niemi-Kiesiläinen and Näre (Nuorisotutkimusverkosto 2000) pp. 137-168; Niemi-Kiesiläinen, Rikosprosessi ja parisuhdeväkivalta [The criminal legal process and intimate-partner violence] (WSOY 2004); Honkatukia, "Ilmoitti tulleensa raiskatuksi" - Tutkimus poliisiin tietoon vuonna 1998 tulleista raiskausrikoksista ['Reported having been raped' - An investigation of rape offences reported to the police in 1998] (Tilastokeskus, Oikeuspoliittinen tutkimuslaitos 2001); Kainulainen, Raiskattu? Tutkimus raiskausten etenemisestä rikosprosessissa [Raped? An study of rape in criminal proceedings] (Tilastokeskus, Oikeuspoliittinen tutkimuslaitos 2004); Kainulainen, Raiskaus - myyttejä ja todellisuutta [Rape - Myths and reality] in Sukupuolistunut väkivalta: Oikeudellinen ja sosiaalinen ongelma [Gender violence: A legal and social problem], eds. Niemi, Kainulainen and Honkatukia (Vastapaino 2017) pp. 214-231; Utriainen 2010; Jokila 2010; Kotanen, Näkymättömästä näkökulmaksi. Parisuhdeväkivallan uhrit ja oikeudellisen sääntelyn muutos Suomessa [From invisibility to a point of view. Victims of domestic violence and the change in legal regulation in Finland] (Unigrafia 2013); Kimpimäki, Raiskauksen määrittelyn kipukohta: Pakottamalla vai ilman suostumusta? [The core of the definition of rape: By force or without consent?] 6 Lakimies (2017) pp. 789-812; Leskinen, Raiskaus 2010-luvulla: Yhä vain väkisinmakaamista? [Rape in the 2010s: Still by force?] in Sukupuolistunut väkivalta: Oikeudellinen ja sosiaalinen ongelma [Gender violence: A legal and social problem], eds. Niemi, Kainulainen and Honkatukia (Vastapaino 2017) pp. 194- 213; Nieminen, Mitä raiskauksen määritelmä kertoo oikeuskulttuuristamme? [What does the definition of rape tell about our legal culture?] in Juhlajulkaisu Kimmo Nuotio 1959 - 18/4 - 2019 [Honorary publication Kimmo Nuotio 1959 - 18/4 - 2019], eds. Frände et al. (Unigrafia 2019) pp. 394-411. For an account of the central criticism in English, see Jokila and Niemi, Rape law and coercive circumstances in Rape in the Nordic countries: Continuity and change, eds. Heinskou, Skilbrei and Stefansen (Routledge 2020) pp. 120-136.

36 GREVIO, Baseline evaluation report: Finland. GREVIO/Inf(2019), p. 165. Authors' emphasis. $37 \quad$ Ibid., p.165. 
GREVIO recommended Finland to 'speedily reform all sexual offences contained in Chapter 20 of the Finnish Criminal Code to fully incorporate the notion of freely given consent. ${ }^{38}$ Also the Committee on the Elimination of Discrimination Against Women (CEDAW) made similar recommendations to the Finnish Government in 2014..$^{39}$ Amnesty International, moreover, has criticised the narrowness of the Finnish legislation at least during the last decade..$^{40}$

At the moment of writing, the Finnish Government is responding to this criticism. In 2019, the Ministry of Justice appointed a working group to evaluate the comprehensiveness and appropriateness of the current law and prepare a draft law that would underline the importance of consent in the definition of rape. ${ }^{41}$

\section{Lessons learned from practice}

Within the framework of the on-going legislative review, the Finnish Ministry of Justice commissioned a research group at the University of Turku to investigate the attrition of rape and other sexual offences in the criminal legal process. ${ }^{42}$ The background of the project was the realisation that attrition rates regarding sexual offences are high in Finland. The project, which presented its final report to the Ministry in April 2020, shed light on how the current law is implemented in practice: not at the level of the Supreme Court or the appellate courts, but during the criminal investigation, by the police and prosecutors, and before first-instance courts. Hence, the project gained insights into legal practice at the lower, albeit crucial, level of the criminal process that strives to investigate and establish the facts of cases. This level is, in fact, the stage of the criminal process in which most reported rapes strand. ${ }^{43}$ Such insights are helpful to determine why the current legal provisions run into problems when implemented and what areas of the law are particularly problematic.

Ibid., p.169.

CEDAW, Concluding observations on the seventh periodic report of Finland. CEDAW/C/FIN/ CO/7 (2014).

Amnesty International, Case closed. Rape and human rights in the Nordic countries (Amnesty International Publications 2010); Amnesty International, Time for change: Justice for rape survivors in the Nordic countries (Amnesty International Publications 2019).

Finnish Ministry of Justice, Decision VN/1984/2019 (11.4.2019). p. 3.

The study covered crimes regulated in The Criminal Code of Finland (39/1889), Chapter 20 Sections 1-5 (rape, aggravated rape, coercion into a sexual act and sexual abuse). The research results are published as Alaattinoğlu, Kainulainen and Niemi, Raiskausrikosten eteneminen rikosprosessissa [The progress of rape offences in the Finnish criminal process]. Oikeustieteellisen tiedekunnan tutkimusraportteja ja katsauksia 1/2020.

Ibid., pp. 52-54. 
The research project analysed cases of rape and other sexual offences that are not investigated, prosecuted or convicted. The research data consisted of decisions made by law enforcement authorities in 2018, selected in a geographically representative way. A total of 232 decisions were analysed: 65 decisions by the police to close a criminal investigation based on that no crime was committed, 113 decisions by prosecutors to limit the criminal investigation or not to prosecute and 54 judgments by first-instance courts to dismiss the charges. It is necessary to point out that the project only analysed cases that did not lead to a conviction, at least at the level of first-instance courts. ${ }^{44}$ This is an obvious limitation of the study. To make more representative observations of recent legal practice, the findings ought to be compared to cases that end with a conviction. In the study, published Supreme Court cases were used as a point of reference.

The project corroborated many findings of earlier studies. ${ }^{45}$ For example, the project found that most victims ${ }^{46}$ of the reported rape offences were women and few were men. ${ }^{47}$ It also found that suspects and defendants were men in almost all cases and often previously acquainted with the victims. Among the relationship-types represented in the material, the most common form was intimate-partner relationships. Around one-third of the cases involved intimate-partner relationships. Moreover, serious physical violence was rarely used in the cases investigated. This was an expected result, as such cases are more likely to lead to convictions. Here, cases that involved intimate partners formed an exception, as some of these cases involved more serious forms of physical violence, such as choking or strangling.

In addition to this, the project also found that many of the victims were in a vulnerable position caused, for example, by young age, intoxication, disability or sleeping. In some cases, the victim was in a vulnerable position due to more than one ground of vulnerability. In such cases, the victim was, for example, intoxicated, young and dependent on the suspect/defendant. Despite these factors, the authorities did not consider the victims to be in a 'state of helplessness' as required by the law. Such conclusions were partly, but not always, based on the lack of direct evidence supporting the claimed vulnerability.

All decisions were not final, as some of the acquittals might have been appealed. The prosecutors nevertheless appeal somewhat sparingly.

$45 \quad$ See, for example, Kainulainen 2004 and Honkatukia 2001.

46 While there were no convictions in the cases, the authors chose to use the word 'victim', rather than, for example, 'plaintiff' or 'injured party' as an acknowledgement of the victimisation experiences of the people in question, despite the outcome of the case. In the material, victims often reported several physical, psychological and social harms, a finding that shows that the experience of victimhood extends beyond the criminal legal conceptualisation of victimhood. was gender-binary. The material did not portray the gender identity of the people involved in the cases. 
Table 1, Compound vulnerability of victims (\%)

\begin{tabular}{|l|l|l|l|}
\hline & $\begin{array}{l}\text { Cases decided by } \\
\text { the police }(\mathbf{N}=\mathbf{6 5})\end{array}$ & $\begin{array}{l}\text { Cases decided by } \\
\text { the prosecutors } \\
(\mathbf{N}=\mathbf{1 1 3})\end{array}$ & $\begin{array}{l}\text { Cases decided } \\
\text { by the courts } \\
(\mathbf{N}=\mathbf{5 4})\end{array}$ \\
\hline $\begin{array}{l}\text { The victim found } \\
\text { to be vulnerable on } \\
\text { more than one (>1) } \\
\text { ground }\end{array}$ & 41,5 & 48,7 & 68,5 \\
\hline
\end{tabular}

The reasons behind the closed investigations and the acquittals were numerous. The most commonly stated reasons were inadequate evidence, that the actions at hand did not fulfil the elements of the crime definition and that victims withdrew from the criminal process. ${ }^{48} \mathrm{~A}$ thorough criminal investigation in which versatile evidence was gathered facilitated the effective process of a case from investigation to trial. In many cases, particularly during the criminal investigation, victims did not benefit from the legal aid or psychological support that they are legally entitled to.

Table 2, Victims' use of legal aid and psychological support persons (\%)

\begin{tabular}{|l|l|l|l|}
\hline & $\begin{array}{l}\text { Cases decided } \\
\text { by the police } \\
(\mathbf{N}=\mathbf{6 5})\end{array}$ & $\begin{array}{l}\text { Cases decided by } \\
\text { the prosecutors } \\
(\mathbf{N}=\mathbf{1 1 3})\end{array}$ & $\begin{array}{l}\text { Cases decided } \\
\text { by the courts } \\
(\mathbf{N}=\mathbf{5 4})\end{array}$ \\
\hline $\begin{array}{l}\text { The victim used legal } \\
\text { aid or support person }\end{array}$ & 3,1 & 4,4 & $94,4 *$ \\
\hline
\end{tabular}

${ }^{\star}$ Only legal aid, not a psychological support person

The research project addressed problems in the interpretation and application of the rape offences in the Criminal Code. The criteria for what is considered as violence and threats of violence varied. In several cases, less grave forms of physical violence, such as slapping, pushing or holding the victim down, were ignored by the decisionmakers.

The interpretation of 'helplessness' was particularly narrow and never implemented in practice in the data. There were cases in which the victim did not, in her own opinion, consent but the suspect/defendant did not have to use serious violence to

48 The sexual offences covered by the study are offences subject to public prosecution. 
coerce the victim to participate in the sexual act. This happened, for example, when the victim was asleep or paralysed by fear. In such cases, the research suggested that if the legislation more clearly emphasised the victim's consent and voluntariness, it would have an impact on the criminal evaluation. In some other cases, however, it was not the legal definitions that caused attrition. Instead, it was a narrow interpretation and a high evidentiary threshold.

One lesson learned from the project is that despite the desire of the Finnish Government to fully protect the rights to personal integrity and sexual autonomy, it might not be enough to revise criminal legislation. The project suggested a more integral approach to the protection of sexual autonomy through, among other things, providing adequate training and resources to law enforcement authorities and thoroughly supporting victims throughout the criminal process. Importantly, the research showed that Finnish police, prosecutors and courts are already to some extent using the concept of consent. Often, however, consent is in practice understood as the polar opposite of coercion, which is, in turn, typically viewed as the use of physical force. Interestingly, hence, it seems that Finnish courts and law enforcement authorities already assign meaning to the concept of consent, despite its absence in the Criminal Code.

\section{The 2020 draft law: Towards voluntariness}

The Ministry of Justice published a report in July 2020, in which it suggested a reformulation and restructuring of the chapter of the Criminal Code that regulates sexual offences. The draftlaw was subsequently sent out for referral to central authorities, civil society actors and experts in order to be transformed into a Government Bill. The Government is likely to present the Bill before the Finnish Parliament during 2021. In the Ministry of Justice report, the section on rape is suggested to take the following form:

$\$ 1$

Rape

'A person who has sexual intercourse with a person who does not participate voluntarily shall be sentenced for rape to imprisonment for at least one year and at most six years. A sentence for rape also follows, if a person:

1) makes another person engage in sexual intercourse with himself or herself or a third person by the use or threat of violence or

2) by taking advantage of the fact that another person is unable to form or express his or her will due to unconsciousness, decreased consciousness, intense intoxication, illness, disability, state of fear or because of the suddenness of the situation, engages in sexual intercourse with him or her.

An attempt is punishable. ${ }^{39}$

49 Finnish Ministry of Justice Report 2020:9, p. 222. Authors' translation. 
The report states that the evaluation of a person's voluntariness - or the lack of such - should be based on external observations of their behaviour. In such an evaluation, both verbal and non-verbal expressions are important. The participation in sexual intercourse cannot be considered voluntary merely based on passivity, that is, on the fact that a person has not expressed her involuntariness verbally or otherwise. Hence, the offence of rape would not require physical or verbal defence or objection from the victim. The report specifically states that a person who is not forced to engage in sexual intercourse is not necessarily participating voluntarily - challenging the earlier-mentioned persisting dichotomy between coercion and consent. ${ }^{50}$

According to the Ministry of Justice draft law and report, sexual intercourse with a person who participates involuntarily is a crime only in its intentional form. The evaluation of criminal intent is an evaluation of whether the accused has understood the externally observable communication between the parties and the verbal and nonverbal actions by the victim. In cases where the victim has not clearly expressed her involuntariness in words or actions, the courts should pay attention to, for example, the relationship between the parties and personal characteristics such as age, maturity, state of intoxication or state of mind. Factors such as a person's revealing clothing, flirtation, seductive dancing, kissing, undressing, ceasing to reject the other person's advances or asking the other person to use protection do not, on their own, indicate an absence of criminal intent according to the report. Instead, the evaluation should take into consideration that the voluntariness of the parties can change, for example, during the course of an evening. The report, furthermore, states that previous intercourses or expressions of voluntariness cannot generally be interpreted to mean that a person voluntarily participates in intercourse also at a later point in time. ${ }^{51}$

The report highlights that the voluntariness to participate in sexual intercourse should be evaluated at the time of the intercourse. The right to sexual integrity continues during sexual intercourse and intercourse that started consensually might develop into a non-consensual one. That the parties regret the intercourse in retrospect, on the other hand, does not mean that it qualifies as rape..$^{52}$

The report also addresses some rape myths, ${ }^{53}$ as it points out that the behaviour of victims can vary. They might not be able to claim the incident as rape immediately. Furthermore, a victim might not conceptualise what has happened as a criminal act, continue a relationship with the accused or report the case to the police after a considerable time. Such behaviour does not, on its own, indicate that the victim

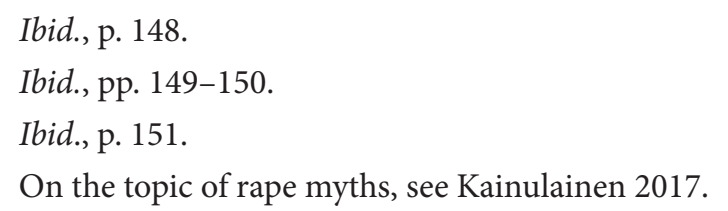


participated voluntarily. ${ }^{54}$

The aim of the second paragraph of the suggested section is to exemplify situations of rape. The two, non-exhaustive examples of rape - through physical force, threat or exploitation - are nevertheless highly reminiscent of the current regulation. The draft section on rape can, hence, be considered a peculiar combination of the current law and a new criminalisation model based on voluntariness as consent.

\section{A new model?}

There are some important differences between the current Finnish section on rape and the one suggested by the Ministry of Justice, but also some similarities. Seen in the draft law, the concept of sexual intercourse is continuously crucial. Sexual intercourse, importantly, is in the Ministry of Justice report defined similarly to the current definition, with the addition of 'touching another person's genitalia or anal passage with sex organ or mouth. ${ }^{55}$ Accordingly, its meaning is suggested to become less concentrated on penetration and, by effect, broadened.

\subsection{Important differences}

First and foremost, despite its only exemplifying situations of rape that are similar to the current regulation, the suggested law moves towards a model based on voluntariness, similarly to, for example, the Swedish rape law after the 2018 amendment. ${ }^{56}$ At the press conference organised at the release of the report, the Finnish Minister of Justice, Anna-Maja Henriksson, expressed the strength of the 'proposed section on rape' as guaranteeing 'a law which better protects victims. ${ }^{57}$ This, she pointed out, was because 'it covers all acts in which the victim has not participated voluntarily.' ${ }^{58}$

Another difference between the current section and the suggested one is in the examples listed. While the types of situations depicted are very similar to the current law, some quite important changes are proposed. Three of the grounds listed in the

$54 \quad$ Finnish Ministry of Justice Report 2020:9, p. 151.

55 Ibid., p. 277. Authors' translation.

56 Swedish Criminal Code (1962:700), Chapter 6 Section 1. Despite some similarities, there are, however, important differences between the Swedish criminalisation of rape and the suggested Finnish criminalisation model. Kimpimäki, Näyttö raiskausrikoksissa: Vapaaehtoisesti vai vastoin tahtoa [Evidence in rape offences: voluntarily or involuntarily], 30 Edilex (2020) pp. 1-16, at 11-14.

57 Yle, Vapaaehtoisuuden puute voi johtaa tulevaisuudessa raiskaustuomioon - Henriksson: "Saamme lain, joka suojaa paremmin uhria" [A lack of voluntariness can in the future lead to a rape sentence - Henriksson: "We get a law, which better protects victims"], https://yle.fi/ uutiset/3-11435483, 7 July 2020. Accessed 14 August 2020. [authors' translation] Ibid. 
second point of the second paragraph, regulating situations of exploitation that qualify as rape, are new. Two of these grounds are 'decreased consciousness' and 'intense intoxication'. According to the Ministry of Justice report, a person might not always be unconscious due to grave intoxication or illness, but this state might weaken a person's intellectual or motoric abilities so that she is unable to form or express her will. A person might, for example, be unable to respond to another person's approaches. The mere fact that a person is under the influence of alcohol or a psychoactive substance is not, however, sufficient to qualify her consciousness as decreased. ${ }^{59}$ This argumentation, accordingly, implies a case-by-case evaluation.

Another new ground added to the section is the 'suddenness of the situation'. The report considers that a situation qualifies as sudden when sexual intercourse is commenced suddenly, when no verbal or non-verbal communication has taken place between the parties and the victim has not had the chance to form or express her will. This could, for example, be sexual intercourse commenced in crowds or in the connection of massage, sauna or swimming. ${ }^{60}$

Importantly, the proposed section also removes the regulation from the current legislation according to which the victim ought to be 'unable to defend himself or herself'. Similarly, it also removes the ground of 'other state of helplessness'. The draft section hence places more importance on the ability of the victim to form or express her will rather than her ability to defend herself. The removal of 'helplessness' also implies that the state a person has to be in, in order to be sexually exploited by another person in a criminally relevant way, does not need to be one where the victim completely lacks agency, but rather, where such agency is compromised.

Another important suggestion is the removal of the third paragraph in the current section. This means that the currently regulated 'less serious' forms of rape would normatively cease to exist. While the implementation of this regulation ought to be limited according to its preparatory works, ${ }^{61}$ as previously explained, the removal of the paragraph at hand can nevertheless be considered as a symbolically remarkable amendment.

\subsection{A typical case}

To test the waters of the suggested law, a typical case from the data of the earlierdepicted research project at the University of Turku can be used as an example. ${ }^{62}$ The case is briefly evaluated according to current legislation and then, tentatively, in the light of the suggested legal amendment. The case at hand was reported to the police,

\footnotetext{
$59 \quad$ Finnish Ministry of Justice Report 2020:9, p. 156.

$60 \quad$ Ibid., p. 157.

61 Finnish Government Bill HE 216/2013 vp, p. 57.

62 Identifying details in the case have been anonymised.
} 
which, in turn, after some time decided that no crime had been committed and closed the investigation.

A was a 16-year-old girl who lived with her parents. She had been on a couple of dates with the 20 -year-old man B. A had told B several times that she was not yet ready to have sexual intercourse. On the day of the event, $A$ and $B$ had met in A's home. They were lying naked on A's bed when B suddenly got on top of A and thrust his penis into her vagina. A was in shock and remained passive. The unprotected intercourse lasted a couple of minutes. After the intercourse, $\mathrm{B}$ asked whether it had been a problem that he had had intercourse with A even though she had not given her permission. A did not respond.

Some days after the event, A went to a doctor, after which she reported the event to the police. She felt troubled by her boyfriend's behaviour but also felt guilty for what had happened.

According to the police, A was not coerced to participate in sexual intercourse through physical force or the threat of such. The police thought it crucial that A had not, through words or actions, rejected B in the situation. According to the police, the fact that $\mathrm{A}$ had told $\mathrm{B}$ earlier that she was not ready for sexual intercourse was irrelevant in the case. According to the police's evaluation, moreover, A had not been in a defenceless position as required by the law. The police closed the investigation considering the elements of the crime not to be fulfilled. ${ }^{63}$

The case is a typical example of the interpretation of the current law. ${ }^{64}$ The current rape section is often understood as a 'checklist', according to which the authorities first pose the evaluative question of whether the suspect/defendant used physical violence or threat of such in order to have a decisive effect on the will of the victim. If this question cannot be answered in the affirmative, the authorities ask whether the victim was in a defenceless position, where she could not defend herself or form or express her will, as required by the law. Importantly, passivity is often interpreted as a sign of approval. ${ }^{65}$

In this typical case, the law enforcement authorities did not consider the factors that rendered the victim vulnerable, such as her young age, the difference in age, maturity or strength between the parties, or the relationship of trust and intimacy between them in evaluating whether the victim was in a situation of helplessness. The fact that the victim did not clearly express her lack of voluntariness was interpreted to mean

63 Alaattinoğlu, Kainulainen and Niemi 2020 pp. 102-103.

64 Examples of similar cases, see Jokila 2010; Jokila and Niemi 2020.

$65 \quad$ Alaattinoğlu, Kainulainen and Niemi 2020 p. 103. 
that the situation did not qualify as rape. In the example, A had previously told B that she was not ready to engage in sexual intercourse yet, which was, remarkably, not given importance in the reasoning by the police. Furthermore, that B acknowledged his awareness of A's lack of approval was not given any evidentiary relevance. ${ }^{66}$

The case represents several similar cases in the earlier-mentioned research data that were similarly evaluated and closed during the criminal process. In light of the whole project material, the decision by the police represented a typical interpretation of the current Finnish section on rape. This is not to say, however, that it was the only one possible. For example, B's actions could be evaluated as use of physical violence; more specifically, that he suddenly got on top of A, which might have prevented A from moving. According to prevalent criminal legal doctrine, ${ }^{67}$ it might nevertheless be difficult to regard the situation as one of physical violence or threat of such, on the one hand, or one where the victim was in a situation of helplessness, on the other.

According to the suggested section on rape, nevertheless, the case would likely have a different interpretation. Firstly, the evaluation of whether A participated voluntarily would likely lead to a different outcome. Accordingly, the fact that A had explicitly expressed her unwillingness to engage in sexual intercourse ought to be given high importance.

Secondly, the addition of the ground 'suddenness of the situation' to the examples listed in the section should make a substantial difference in the evaluation of the case. Accordingly, A did not reject or respond to B because of her state of shock caused by B's sudden behaviour. Hence, the specific addition of the ground speaks for the case being legally interpreted as rape.

Thirdly, the draft law, read in light of the arguments in the report, moves towards a more contextually sensitive evaluation of the situation. According to the report, what is taken into consideration is no longer merely the moment of sexual intercourse even though the emphasis in the evaluation of voluntariness temporally lies at this moment. But apart from this, the sphere of legal relevance is broadened. Factors such as the relationship between the parties, their communication at the moment of the intercourse and prior to it, as well as any differences in age, maturity or state of mind, should, hence, be taken into consideration. In the case at hand, taking into consideration these factors - along with that B was seemingly aware of A's lacking voluntariness based on previous communication and experience - further strengthens the impression that the case would be regarded as rape.

Finally, according to the Ministry of Justice report, passivity would not as such mean that a person voluntarily participates in a sexual encounter. According to the draft

\footnotetext{
$66 \quad$ Ibid.

67 See, for example, Finnish Supreme Court KKO:2013:96.
} 
law, the fact that A had not rejected B because of her state of shock would hence not rule the case out from qualifying as rape, which the interpretation of the current law suggests.

In the case investigated, an application of the 2020 draft law would lead to a different evaluation. The case, hence, renders visible important changes when comparing a typical interpretation of the current law and a likely interpretation of the suggested definition of rape. However, this does not mean that the draft law is complete in its current form.

\subsection{Voluntariness within limits}

The draft law by the Ministry of Justice moves towards an increased emphasis on the lack of voluntariness of the victim. There are, however, some problematic points in the formulation of the legislation that should be taken into further consideration. Two of these, discussed in the following, are the failure to consider the impact of intimatepartner violence when evaluating a person's voluntariness and the apparent limitation of the draft section on rape through maintaining a separate section on sexual abuse.

While the draft law and the report mention that relationships and earlier communication between parties ought to be taken into consideration, the documents do not spend many words on violence in close relationships. The report states that such earlier violence can be taken into consideration when evaluating a specific situation, namely whether the victim has been in a 'state of fear' or not. ${ }^{68}$ As the earliermentioned research project has shown, many of the reported rapes and other sexual offences in Finland concern intimate partners. In many of these cases, the victim was subjected to physical, mental and emotional violence before, during and after the reported sexual offence took place. ${ }^{69}$ In some cases, the accused had already received a sentence for such acts of violence. These situations should not, however, be assessed only in the light of the ground of 'state of fear', but more broadly in the context of voluntariness. Accordingly, when a person is repeatedly victimised by her partner, her possibility to freely decide on sexual interaction may be seriously compromised, which ought to be taken into serious consideration in the legal evaluation. ${ }^{70}$

The Istanbul Convention, furthermore, highlights that violence committed by intimate partners, family members or cohabitants ought to be an aggravating factor in criminal evaluations. ${ }^{71}$ In the law drafted by the Ministry of Justice, however, the close relationship between victim and perpetrator is not regarded as such. This point

Finnish Ministry of Justice Report 2020:9, p. 153, 156. See also Kimpimäki 2020 p. 15. See Jokila 2010; Jokila and Niemi 2020.

See Alaattinoğlu, Kainulainen and Niemi 2020 pp. 117-123.

See Article 46 (a). Overall, the draft proposes only minor revisions in the aggravating factors of rape. The Finnish Ministry of Justice Report 2020:9 p. 255. 
of criticism is not to say that a person subjected to violence by her partner has no agency or that she cannot voluntarily participate in sexual encounters. ${ }^{72}$ It is mainly a reminder that it is important to take into consideration the larger context in the criminal evaluation of the situation, especially when it involves a violent relationship.

The concept of voluntariness in the draft law is, moreover, watered down by the offence of sexual abuse (Section 5). This draft section is a modification of the current offence, especially considering the abuse of positions of trust or relationships of special dependence. It includes sexual exploitation of young people aged 16 or 17 years $^{73}$ in schools, institutions, work relationships and it also protects young people with reduced maturity. In addition, the section protects adults who are in care institutions or in a care relationship with the perpetrator. The section emphasises victims' special dependence and subordinate positions and perpetrators' persuasion and exploitation. The offence of sexual abuse carries a maximum penalty of four years' imprisonment, in comparison to the maximum penalty for rape, which is six years and ten years for aggravated rape.

The proposed regulation of sexual abuse is conceptually confusing in relation to rape as defined by the lack of voluntariness. The elements of sexual abuse cover situations in which the possibility of the victim to decide freely on participation in sexual activity is limited at best. At worst, the person in the dominant position exploits the dependent party. Today, professional codes of ethics univocally prohibit such relationships. From the point of clarity, a specific section on such forms of sexual abuse may be useful. The new section on rape based on the lack of voluntariness is, nevertheless, also relevant in the assessment of such relationships of dependence. A specific section on sexual abuse with a lower sentence scale, as opposed to the examples listed in the section on rape, hence seems to downplay the protection of the integrity and autonomy of people in dependent positions.

\section{A look to future implementation}

This article has investigated theoretical and practical challenges that the current Finnish definition of rape faces. Depicting how consent has become a more important supranational normative model, the article also discovers a similar trend in Finland, particularly embodied by the 2020 draft law on rape and other sexual offences. Interestingly, the Ministry of Justice report in which the draft law is included advocates for an apparently new, contextual and communicative model for criminally evaluating sexual encounters and, more specifically, whether a person participates voluntarily or not. The model takes into consideration factors such as power imbalances, the

\footnotetext{
72 This has been taken into consideration by the working group that has drafted the law, as pointed out by Kimpimäki 2020 p. 15.

73 The age of consent is 16 , both according to the law in force and the draft law.
} 
relationship between the parties, verbal and non-verbal communication. This model is very different from the model entailed in the current law, which builds on a more restricted understanding of rape as use and threat of violence, force and exploitation.

Moving towards a different legal model nevertheless implies a difference in legal, social and cultural thinking. ${ }^{74}$ This involves, for example, a thorough criminal doctrinal discussion on the meaning of voluntariness, a rewriting of criminal law textbooks and allocation of resources to train and educate judges, prosecutors and police officers in the meaning of the new legislation, its interpretation and implementation. Such education ought to take into consideration challenges in implementing the law, for example, the prevalence of rape myths among law enforcement authorities. Moreover, as discovered in the earlier-mentioned research project on attrition of sexual offences, enforcing the rights to personal integrity and sexual autonomy of victims of sexual violence also entails the provision of thorough support services for victims. This can be done, for example, by offering legal aid and comprehensive psycho-social rehabilitation services. Sexual offences should also be prioritised by law enforcement authorities and a thorough and effective investigation of evidence, including victims' harms, should always be carried out. ${ }^{75}$ Importantly, in order to move towards a more substantial model of consent, building on a person's voluntary participation, as envisioned by the Ministry of Justice, more than merely changing the wording of the definition of rape is needed.

The risk of not addressing these practical points is that a new law is introduced in the books, but an old version of the law remains enforced in practice by the authorities. The inclusion of only two examples of rape in the draft law, which are similar (albeit not identical) to the current law's conceptualisation of rape, reinforces such a risk. The existence of non-exhaustive lists in the definition of criminal offences could be considered foreign to Finnish criminal legal tradition, as lists in the Finnish Criminal Code are generally exhaustive and specific. Furthermore, such a list might also be problematic from the point of view of the principle of legality. Here, the inclusion of more illustrative, comprehensive legislative examples of how the new section is thought to differ from the previous model would be helpful. This is particularly true if the thought behind the legal amendment is to widen the scope of implementation. Otherwise, the interpretation of the suggested section might be unclear, causing general legal uncertainty. In a situation of such confusion, there is a great risk that law enforcement authorities prefer the known to the unknown and interpret involuntary participation in sexual intercourse according to the current, restrictive checklist of

74 Similar points have also been made, for example, in Nieminen 2019; Leskinen, The Istanbul Convention on sexual offences: A duty to reform the wording of national law or the way we think? in International law and violence against women: Europe and the Istanbul Convention, eds. Niemi, Peroni and Stoyanova (Routledge 2020) pp. 133-156; Leskinen, Towards a new ethics of sexual self-determination: Finnish rape law through the speculum of feminist philosophy, 17 NoFo (2019) pp. 78-105.

75 For a complete list, see Alaattinoğlu, Kainulainen and Niemi 2020 pp. 132-134. 
Bergen Journal of Criminal Law and Criminal Justice • 2/2020

examples enlisted in the section on rape. 